\title{
The inward crusade: the apocalypse of the Queste del Saint Graal
}

\author{
Marco Nievergelt
}

Received: 10 April 2006/Accepted: 1 November 2006/Published online: 24 May 2007

(C) Springer Science+Business Media B.V. 2007

\begin{abstract}
The Queste del Saint Graal is the most intensely spiritual of the medieval Arthurian romances, and in its combination of chivalric and religious material immediately calls to mind the contemporary phenomenon of the crusades. The text at once seems to resist the drive towards exteriorisation expressed in the crusading impetus, counterbalancing it by a mystical internalisation of the focus and objective of the quest. As such, through its use of apocalyptic imagery, the text redefines the eschatological expectations that contemporaries projected onto the crusades to the Holy Land. Redirecting such an eschatological focus inward, aimed towards the purification of the heart of each individual Christian in preparation for the imminent apocalypse, the Queste is nevertheless forced to confront yet another intensely real threat originating from within Christianity itself, that of the Cathar heresy. Cultivating a constant and uneasy ambiguity about the status of the text itself, swinging between lofty allegorisations and stark, physical realism, the author finally sees the repression of the Cathar heresy as part of a wider process of purification fulfilling a clearly eschatological function. The apotheosis of the text, with the companions' entirely peaceful recovery of the eschatological, 'celestial city' of Sarraz, is thus seen as the result of a form of 'inward crusade' that is at once physical and ideological, micro and macrocosmic but always directed towards the heart of Christianity itself rather than the infidel.
\end{abstract}

Keywords Crusades $\cdot$ Apocalypse $\cdot$ Knighthood

\footnotetext{
M. Nievergelt

Lincoln College, University of Oxford, OX1 3DR Oxford, UK

M. Nievergelt $(\bowtie)$

Département de langue et littérature anglaises, Faculté des Lettres, Université de Genève, Uni Bastions, 5, rue de Candolle, Geneve 1211, Switzerland e-mail: marco.nievergelt@lettres.unige.ch
} 
The French Queste del Saint Graal is, in more than one sense, an apocalyptic work. In the narrow, textual universe of the Vulgate cycle, the Queste recounts the apocalypse of the knightly world of Logres, its disintegration and sublimation into the chevalerie celestiel hailed by the advent of Galaad. ${ }^{1}$ The destruction of the worldly order of the Round Table goes hand in hand with the establishment of a new order based upon a new system of values, and this process takes the form of a separation of the elect from the damned. ${ }^{2}$ The elect, the three companions, are clearly represented as departing from the sinful and senseless multitude of the 'herd' of Arthur's knights in one of the numerous dream visions that punctuate the quest for the Grail (p. 149). ${ }^{3}$ Their participation in the Grail ritual of Corbenic (p. 267 ff.), together with nine other knights to make up the symbolic number of 12, acts not only as a repetition of the original sacrament of the Eucharist first administered by Christ to his disciples during the Last Supper, but also reverberates with apocalyptic echoes. In the Queste's complex use of typology this Eucharistic ritual is both postand pre-figurative, ${ }^{4}$ echoing a number of features found in the book of Revelation, itself playing a crucial role in the genesis of the liturgy. ${ }^{5}$ Thus the 12 elect knights mirror not only the apostles but equally prefigure the 24 Elders attending the eternal liturgy in Rev. 4:4, as well as the one hundred and forty-four thousand (12 x 12) elect from Rev. 7:4. ${ }^{6}$

Typologically speaking the rise of Galaad in the Queste comes to occupy a central position in the history of salvation between the First and Second Coming of Christ, and is therefore understood as a sort of 'middle advent', pre- and postfigurative at once, similar to the one conceived by the Cistercian Guerric of Igny. ${ }^{7}$ The mystical revelation experienced by Galaad and the other companions is a truly spiritual process that corresponds to the traditional Augustinian definition of the apocalypse as a microcosmic experience, taking place outside of space and time in the soul of the individual believer. ${ }^{8}$ This obviously reflects the primarily mystical

\footnotetext{
${ }^{1}$ Combarieu (1995) speaks of the Mort Artu as representing the eschatology of the Arthurian chivalric world, preceded by the Queste, that in symbolic and allegorical form already constitutes its apocalypse, intended as a Pentecostal 'revelation' of the divine truth concealed beneath the illusory surface of the Arthurian world.

2 This separation implies an ideological break between the two chivalries, earthly and heavenly, which in its turn, according to Bogdanow (1986), is equally reflected in the ideological discontinuity between the Queste and its continuation in the Mort Artu. The Mort in fact returns to a system of values that is more traditionally chivalric, and sees the downfall of the Arthurian world as resulting from the workings of fortune rather than the sinfulness inherent in earthly chivalry as is the case for the Queste.

3 All references are to the text established by Pauphilet (1923).

4 For the Queste's use and understanding of typology, see Matarasso (1979, pp. 18-37); on the final ritual at Sarraz as an eschatological Eucharist, ibid. p. 80. For the emphasis on the Eucharist in particular see Vallery-Radot (1956b, p. 200); and Hamilton (1942).

5 Piper (1951).

6 All biblical references are to the New Jerusalem Bible (London: Darton, Longman and Todd, 1985, 1994).

7 Matarasso (1979, p. 223).

8 This notion was first formulated by Origen and developed by the later Fathers, cf. Cohn (1957, p. 29).
} 
focus of the Queste and its concern with the progress of man from his earthly self towards the spiritual revelation that requires - and in fact coincides with-the sacrifice of one's individuality in the manner of an imitatio christi.

While all of this points towards a sphere of purely mystical and universalising signification, I would like to argue that yet another dimension of the Queste's apocalypticism, on the other hand, allows its placement within a precise historical context. Far from being simply concerned with trans-temporal realities as such, the Queste is also concerned with the relationship of such spiritual realities to the temporal, historical world, ${ }^{9}$ and therefore reflects preoccupations that are characteristic for the historical moment that saw its creation, generally placed between 1220 and $1230 .{ }^{10}$ Also, its apocalyptic dimension is not restricted to the plane of microcosmic mystical experience, but extends to embrace that of the contemporary historical reality that is itself perceived through an apocalyptic lens. In its blend of a literal and an allegorical understanding of the knightly expedition, culminating in a journey beyond the sea to the 'palès espirituel' under heathen rule in Sarraz, the Queste is in fact unmistakeably drawing from the imaginative storehouse that characterised the contemporary perception of the crusades, themselves heavily imbued with apocalyptic overtones. ${ }^{11}$ Yet so far the work's relationship to the crusades and to crusading mentality more generally has attracted very little attention, possibly in reaction to the text's own implicit claim to transcend historical specificity thanks to its use of a universalising typological reading of human events. ${ }^{12}$ But, since it can also be argued that such a universalising understanding of history is itself a product of the specific historical moment and context, it appears that the text entertains a complex and ambiguous relationship to the 'reality', both historical and ideological, of the crusades. ${ }^{13}$ In the rest of this article, rather than presenting yet another 'reading' of the Queste as such, ${ }^{14}$ I therefore propose to discuss the significance of the text in the context of the apocalyptically connoted crusading mentality of the early 13 th century.

\footnotetext{
${ }^{9}$ As Pauphilet (1921, p. 114) has pointed out, the Queste-author is not interested in the writing of a paradigmatic, prudentian allegory, but rather in the portrayal of Prudentius' abstractions in action, and therefore within a specific context and historical moment.

${ }^{10}$ Cf. Barber's (2004, p. 373) chronological table of the major Grail romances; Matarasso (1979, pp. 205-206) narrows down the time of composition to the period between 1225-1230.

${ }^{11}$ Cohn (1957, pp. 53-126); Carozzi (1999, pp. 101-110); Andrea (2004); Reeves (1984); Trotter (1988).

12 The laudable exception is Knight (1994), who connects the rise of Arthurian Romance more generally with the decline in the crusading enthusiasm. A large amount of work has been done, on the other hand, to explore the influence of more specifically Cistercian theology, and the Order's role in shaping the Templar ideal that appears to be echoed in the Queste; see e.g., Pauphilet (1921); Barber (2003); Pratt (1995); Saycell (1991); Isabel Mary (1976); Vallery-Radot (1955, 1956a, 1956b).

${ }^{13}$ The imaginative perception of the crusades, with all its protean variety in answering the Christian West's needs for religious self-definition and the rich possibilities for imaginative projection, has taken centre stage in recent Crusading scholarship, e.g., Tyerman (1998) and Ridyard (2004).

${ }^{14}$ Among the most influential full-length studies of the Queste it is worth mentioning in particular Pauphilet (1921); Gilson (1932); Matarasso (1979); Williams (2001).
} 
It is first of all necessary to isolate a number of features that lend the text its peculiar apocalyptic mood. The companions' affinity with the elect of the Book of Revelation was already mentioned, and is strengthened by the emphasis placed upon their virginity or chastity (cf. Rev. 14:3-4), an assimilation that is further emphasised in Galaad's case by the continuous references to his white clothing also worn by the elect. Galaad in particular has also been repeatedly assimilated with Christ himself because of a number of shared symbolic features: he is portrayed as a pre-figuration of Christ the apocalyptic horseman, both redeemer and judge. ${ }^{15} \mathrm{He}$ is also the bearer of the sword found on the ship of Salomon, at once figure for the sword of the divine verbum and apocalyptic attribute of Christ (Rev. 1:16 and $19: 15),{ }^{16}$ while the crown he finds on the same ship assimilates him to the messianic king of the heavenly Jerusalem (Rev. 14:14 and 19:11-21). Another detail echoing the account of Revelation is the repeated appearance of writing on people's foreheads. The writing only appears on the foreheads of Christ himself and Josephus, who both act as envoys of the spiritual and post-apocalyptic world. Christ appears to Perceval wearing a crown of white samite bearing the letters glorifying the name of Our Lord (p. 99), which echoes his description in Rev. 19:12: "the name written on him was known only to himself', as well as that of the one hundred forty-four thousand elect from Rev. 7:3 and 14:1. ${ }^{17}$ One further object carrying apocalyptic connotations is the Ark built by Galaad to store the Grail after his coronation as King of Sarraz. In its typological relationship to the Ark of the Covenant it obviously acts as its fulfilment and completion, which is also suggested by Rev. 11:19 where the Ark is revealed after the seventh trumpet blast in God's sanctuary in heaven. ${ }^{18}$ But the description of Galaad's Ark, both because of its rectangular shape and material, suggests that it is at the same time also a figure of the Holy City itself: it is "une arche d'or et de pierres precieuses" (p. 277), just like the City is "of pure gold" and "the foundations of the city wall were faced with all kinds of precious stone" (Rev. 21:18-19).

More importantly, beyond such isolated items that are inspired by the biblical account of the apocalypse and its symbolism, a number of episodes in the Queste and even its general narrative structure reflect apocalyptic patterns. The final phase of the companions' journey in particular is saturated with apocalyptic echoes. Their encounters and battles, rather than being elements in an individual psychomachia as in the earlier stages of their journey or in Lancelot's quest, are increasingly described in terms of an eschatological battle where the companions become

\footnotetext{
15 Pauphilet (1921, p. 141).

16 Matarasso (1979, pp. 65-66).

${ }^{17}$ For Josephus see Queste p. 268; cf. Williams (2001, p. 139). Pauphilet (1921, p. 91) also suggests the possibility of an apocalyptic influence for this feature but ultimately decides against it opting for a different, iconographical reading.

18 Matarasso (1979, p. 209) in her typological reading of the Queste sees an internal progression moving from a symbolic tabernacle (the Grail in the chapel in the forest) to the Ark accompanying the chosen people on their pilgrimage (the Grail on the Ship of Solomon) to the final apotheosis of the Ark in Sion, signified by the Grail within the Ark at Sarraz.
} 
instrumental in the accomplishment of divine justice. Thus the tone of the exegesis offered by the priest liberated after the massacre of Carcelois invites the companions' identification with the heavenly hosts themselves on the day of the final battle and evokes the divinely ordained vengeance manifested in the destruction of the sinful Babylon (cf. Rev. 18 and 19): "vos avez fet la meillor oevre que chevaliers feissent onques mes. Et se vos viviez autant comme li monde durra, ne cuit je mie que vos peussiez fere ausi bone aumosne come ceste est. Si sai bien que Nostre Sires vos I envoia por ceste oevre. Car il n'avoit gent au monde qui tant haissent Nostre Seignor come li troi frere qui cest chastel tenoient.', (p. 231). The same mood, a surprising shift from the Queste's earlier unconditional condemnation of manslaughter, ${ }^{19}$ again pervades the next episode of violence as we approach the text's spiritual apotheosis. The sacrifice of Perceval's sister to save the leprous lady, while it is also an imitation and repetition of Christ's sacrifice, is again saturated with apocalyptic echoes. So while Perceval's sister and the other virgins who had previously given their blood to cure the leprous Lady represent the company of martyrs and saints, the Lady, in the light of the familiar correspondence between leprosy and sins of the flesh, ${ }^{20}$ can be identified with the whore of Babylon, "drunk with the blood of the saints, and the blood of the martyrs of Jesus" (Rev. 17:6). In this light the storm that destroys the castle after the attempted healing again echoes the plague of the seventh bowl (Rev. 16:17-21) and the destruction of Babylon (Rev. 18), manifestation of divine wrath and vengeance: "Nostre Sires les avoit foudroiez et tempestez por la mauvese vie qu'il avoient menee entr'ax", (p. 244). Significantly the companions witness the destruction of the sinful castle/ city from a distance, taking shelter from the storm in a chapel, as if to echo the apocalyptic injunction: "Come out, my people, away from her, so that you do not share in her crimes and have the same plagues to bear' (Rev. 18:4). On returning to the destroyed castle Perceval and Galaad find the hidden tombs of the previously martyred virgins (p. 245), just as in Babylon "was found all the blood of prophets and saints, and all the blood that was ever shed on earth"' (Rev. 18:24).

Yet the most distinctively and powerfully apocalyptic element in the Queste is its apotheosis and final destination, the 'palès espirituel' beyond the sea in Sarraz, figure of the New Jerusalem. ${ }^{21}$ Following the active events at Carcelois and the Leprous Castle, the companions now embark on a contemplative journey into the heart of the Christian mystery of the Real Presence in the liturgy of the Eucharist. The vision of the white hart in the forest surrounded by the tetramorph has its direct equivalent in the description of the eternal liturgy in Rev. 4:6-11, where the appearance of the tetramorph functions as a prelude to the actual Revelation of God and the coming of the New Jerusalem. Similarly in the Queste it represents the beginning of the truly 'revelatory' and purely spiritual phase of the journey. For the

\footnotetext{
19 Rather than being the act of manslaughter as such that is called into question, it is always the spiritual state of the knight perpetrating it that determines the real significance of such an act. This also explains how Gauvin's condemnation can stand alongside the praise and exaltation of Galaad for what in both cases externally appears to be an identical act of violence. Cf. Matarasso (1979, p. 59).

20 Pauphilet (1921, p. 114).

21 Critics generally concur in associating Sarraz with the Holy City, cf. Matarasso (1979, p. 80); Knight (1994, p. 231); Saycell (1991, p. 5).
} 
companions this is the first of a sequence of three celebrations where the central mystery of Christian faith is revealed with a progressively increasing degree of depth and directness. This series of meta-liturgical rituals leads up to the final and direct manifestation of the Divine itself, stripped of all its forms, even the symbolic ones. $^{22}$ It is, properly speaking, a process of revelation, the progressive removal of the symbolic veils that at once hide and 'contain' the mystery. The second phase of this process sees the companions' arrival at the castle of Corbenic, where they are joined by the other nine elect knights for the celebration of the Grail liturgy, repetition of the original Eucharist and anticipation of the final, liturgical apocalypse of Rev. 11:15-19. Yet the actual culmination of the Queste is obviously the Mass celebrated by Josephus at Sarraz. This again can be linked with the actual climax of the book of Revelation, where the servants of God "will see him face to face" (Rev. $22: 4$ ), as a fulfilment of the promise of 1 Cor 13:12. A number of critics have pointed out that the Queste's use of preponderantly visual figures during this last ritual suggest that this is in fact exactly what happens to Galaad: ${ }^{23}$ " car ore voi ge tot apertement ce que langue ne porroit descrire ne cuer penser." (p. 278). Significantly after the incommunicable contemplation of the Face of God, Galaad is taken up to heaven and thus finally accomplishes the transition from the earthly to the heavenly Jerusalem. ${ }^{24}$

\section{II}

The ultimate focus and culmination of the journey in Sarraz, city beyond the sea under heathen rule and figure of the twofold, earthly and heavenly Jerusalem, invites the exploration of additional points of contact between the Queste and the contemporary, imaginative understanding of the crusades. ${ }^{25}$ The Queste, in fact, seems to be influenced less by specific, topical episodes connected with the crusades than by the wealth of imaginative and symbolic conceptions with which contemporaries responded to the phenomenon. The apocalyptic perception of the crusades removes them from the plane of ordinary, human time and awards them a privileged position in the history of salvation, connecting them directly with man's eschatological destiny. Ever since the first crusade, thanks to the convergence of literal reality and symbolic ideas, the recovery of Jerusalem was perceived to be closely related to the advent of the celestial Kingdom. ${ }^{26}$ The exact manner in which this connection was felt, could vary from that of a simple pre-figuration as in the

\footnotetext{
${ }^{22}$ Cf. Pauphilet (1921, pp. 93-102); Matarasso (1979, pp. 184-187).

23 Lot-Borrodine (1951, pp. 159); Matarasso (1979, pp. 196-198).

24 Matarasso (1979, p. 210).

25 Upon arriving in Sarraz the companions are thrown into prison by its heathen ruler Escorant (p. 276). It can hardly be a coincidence that in 1213 Innocent III, in his epistle Quia maior, proclaiming the 5th crusade and sent to all provinces of the Christian west, had spoken, in classical papal rhetoric, of "Christians imprisoned and enslaved by the Saracens in Jerusalem', cf. Riley-Smith (1981, p. 120).

26 Carozzi (1999, pp. 103 ff.); Cohn (1957, pp. 53-126); Reeves (1984, pp. 45-48). Trotter (1988, pp. 25, 132, 187-189 and passim) has demonstrated the pervasive impact of this notion on the entire spectrum of so called crusading literature.
} 
case of St. Bernard, all the way to an unconditional identification as was the case with certain radical millenarian movements. ${ }^{27}$ The renewed loss of Jerusalem to Saladin in 1187 had again sparked and revived a number of apocalyptic prophecies predicting the imminent recapture of the city through the appearance of the mysterious messianic Emperor of the Last Days, reigning in Jerusalem as prelude to the coming of Antichrist and the eschatology brought about by Christ's Second Coming as judge. ${ }^{28}$ The renewed fervour with which the people, rather than the élite of western Europe, sought the recapture of Jerusalem after 1187 and in particular after the morally disastrous display of greed and self-interest of the fourth crusade against Constantinople is reflected by the numerous people's and children's crusades launched in the early 13 th century. ${ }^{29}$ The complex phenomenon of such popular, apocalyptically connoted crusading enthusiasm is characterised above all by its belief in the possibility of contributing to the advent of the millennium through a collective and active human effort independent of a direct divine intervention. ${ }^{30}$ The identification of the infidel hordes with the host of Antichrist, or one of his many pre-figurations or 'types', had been current since the emergence of the prophecies of the pseudo-Methodius in the 7 th century ${ }^{31}$ and invited further speculation about the exact modalities and chronology of the Last Things preceding Judgement Day.

While it is clear that the Queste reacts to this general ideological climate both through its use of crusading imagery as well as by generating an apocalyptic climate within the text, it is far more difficult to assess the exact nature of the work's position in relation to its context. The Queste in fact refuses to integrate and perpetuate any of the popular prophecies foretelling the imminent fall of the Holy City as the result of a collective, human effort. Its apocalypticism is of a radically different nature from that of the contemporary millenarian frenzy; rather than exhorting a collective, outward effort of the entire Christian West towards the recapture of Jerusalem and the ensuing advent of the celestial Kingdom, the Queste adopts an almost anti-interventionist agenda, focusing on a highly personal and inward movement towards a more traditional and orthodox apocalypse of the spirit. It is striking, to say the least, that the three companions never fight the heathen on their Journey towards Sarraz. Even the transition of the kingship of Sarraz from

\footnotetext{
${ }^{27}$ In the De Laude Novae Militiae ad Milites Templi (III,6), in praise of the Templars and in support of the crusades more generally, St. Bernard writes: "Of course we must not let these literal fulfilments blind us to the spiritual meaning of the texts, for we must live in eternal hope in spite of such temporal realisations of prophetic utterances. [...] The temporal glory of the earthly city does not eclipse the glory of its heavenly counterpart, but rather prepares for it, at least so long as we remember that one is the figure of the other', in St. Bernard (1977, p. 137). For the millenarian identification and confusion of the two Jerusalems, see Cohn (1957, p. 65 and passim). For the dominant view held by the papacy in the period, itself fundamentally chiliastic albeit moderately so, see Andrea (2004).

28 Carozzi (1999, p. 110). The chronology of the events marking the advent of the last days was often confused and contradictory, thus the actual millennium could for instance precede or follow the coming of Antichrist depending on the specific prophecy considered, cf. Emmerson (1981, pp. 49 and 58-60).

29 Cohn (1957 pp. 71-113); Riley-Smith (1987, pp. 141-145); Mayer (1972, pp. 214-227); Runciman (1955, pp. 139 ff.).

30 Emmerson (1981, p. 58).

31 Emmerson (1981, pp. 48, 67); Cohn (1957, p. 32).
} 
Escorant to Galaad is entirely peaceful and bloodless, (p. 277) a detail that after the massacres of Carcelois and the Leprous Castle cannot be discarded as meaningless, and will be discussed below. The Queste thus offers an alternative picture of the apocalypse as a spiritual, microcosmic process that is again situated within the soul of the individual believer, in an allegorical rather than a physical locus, thus restoring the orthodox patristic conception that appears completely eclipsed in the contemporary millenarian prophecies. ${ }^{32}$ Similarly its object, the ineffable grail, invisible embodiment of divine grace or of the intimate mystery of transubstantiation, ${ }^{33}$ could not be further removed from the harsh outward reality of the recent disastrous crusades against Constantinople or Damietta and the tragic epilogues of the smaller popular crusades. ${ }^{34}$

Yet this withdrawal from the vicissitudes of the outward world into the intimacy of the contemplation of fundamental mysteries of the Christian dogma, is not simply a reiteration of a traditional, conservative perspective, but can itself be seen as a conscious reaction against the increasing political and economic pragmatism and cynicism motivating the expeditions outremer. ${ }^{35}$ In this sense the Queste can be seen as partaking in a generalised contemporary tendency to view the crusades more critically. Such criticism, though, was hardly directed against the actual principle of Holy War, and rather tended to address the specific modalities for putting the commonly shared ideal of a just religious war into practice. ${ }^{36}$ The crusades' lack of success was increasingly felt to be a direct consequence of the inappropriate spiritual disposition of the crusaders themselves. ${ }^{37}$ Both the fourth and fifth crusade had proven politically and spiritually disastrous: directed against Constantinople and Damietta, respectively, this strategic movement of the military target away from the Holy City, symbolic heart of Christianity, was to many a fitting image for the moral decline of the crusaders, only too happy to replace their former religious fervour with politically and commercially minded expansionism. Appeals by contemporary chroniclers and commentators for a need, above all, to regenerate the inner, moral disposition of the crusaders themselves reach an intensity and frequency previously unheard of. ${ }^{38}$ The reasons for the Christians' defeat increasingly tended to be attributed to their moral corruption and sinfulness, making them unworthy of receiving divine grace and aid. In particular the

\footnotetext{
32 For a comparison of the orthodox, Augustinian position with the millenarian heterodoxy, see Emmerson (1981, pp. 56-59). See also Cohn (1957, pp. 29 ff.).

33 For these two differing interpretations see respectively Gilson (1932) and Hamilton (1942).

34 Knight (1994) sees the Grail itself as a literary object functioning as providing an immaterial, imaginary surrogate to compensate for the loss of the actual Holy City.

35 For the motivations to launch the new crusades see Mayer (1972, pp. 196-224); Runciman (1955, pp. 107-170); Cohn (1957), pp. 89 ff.; for the impact of this new pragmatism on the crusading ideal as reflected in the literature of the period see Spiewok (1989); and Isabel Mary (1976, p. 58).

36 Siberry (1985, pp. 89-103).

37 This concern is especially prominent in Innocent III's epistle Quia Maior from 1213, which is symptomatic of Innocent's wider project of redefinition of the nature, modalities and significance of the Crusades. Cf. Riley-Smith (1987, pp. 143-145).
}

38 Siberry (1985, pp. 98-103). 
castigation of the sins of the flesh by contemporary chroniclers after the fall of Damietta $^{39}$ may well have contributed to push the author of the Queste to place such emphatic importance on the chastity of his heroes.

It can be said that the loss of Jerusalem in 1187 prompted two different, even opposite reactions in the West. On the one hand it revived millenarian hopes that a renewed liberation of the City would this time bring about the long awaited heavenly Kingdom, while on the other, with the more disillusioned and carefully sceptical Christians, it effected an increased internalisation and spiritualisation of the goal to be achieved. This prompted a redirection of the spiritual focus from the hope for a literal, prophetic resolution within human history to the quest for an inward, mystical revelation, and thus in turn accelerated the rise of orthodox piety. ${ }^{40}$ This accounts not only for the Queste's interest in the inward, Eucharistic dimension of the apocalyptic process, but also helps to put its doctrinal didacticism into perspective. ${ }^{41}$ The text does not simply suggest an alternative form of apocalyptic thought, but in doing so attempts to 'correct' and regenerate the heterodoxy of the fundamentally dualist millenarian speculations. By exploiting the sacramental symbolism of the Real Presence, the text directs its readers' attention towards an exploration of the central mystery of the Christian faith, ${ }^{42}$ and in doing so distracts them from any search for an outward, literal realisation of apocalyptic expectations. ${ }^{43}$ This internalisation equally functions as a purification and regeneration of the fundamental Christian allegory of the apocalyptic 'journey' to the heavenly Jerusalem that had become so tragically 'literalised' by the recent history of the crusades. ${ }^{44}$ Thus Galaad's kingship of Sarraz, while it is possibly inspired by the numerous prophecies about the emergence of an Emperor of the Last Days reigning in Jerusalem, is meant to function on a purely allegorical level and acts as a simple prelude to his mystical apotheosis during the final, direct contemplation of the divinity "face to face", (Rev. 22:4). By casting Galaad in the guise of a priestly king of Sarraz rather than an ordinary worldly King, the Queste-author may well be incorporating a Joachimist idea that had begun circulating in the early 13th century. ${ }^{45}$ Furthermore, by representing Galaad's kingship not only as an almost collateral consequence of a spiritual rather than military undertaking, but by making

\footnotetext{
39 Siberry (1985, pp. 102-103).

40 Cf. Carozzi (1999, pp. 109-110).

41 On the Queste's didacticism see Pauphilet (1921, pp. 85 ff.).

42 Pauphilet (1921, pp. 93-95).

43 Cf. also Knight (1994, pp. 230 ff.).

44 In doing so, the Queste-author once more reiterates the allegorical conception of the miles Christi and the crusade that pervades St. Bernard's De Laude, cf. Baumgartner (2003, pp. 111-112); Vallery-Radot (1955, p. 213).

45 The prophecy of the Emperor of the Last Days, as transmitted by the tradition following the pseudoMethodious, predicted the Emperor's triumph in Jerusalem, culminating with his abdication of power, surrendering his crown to the Almighty; cf. Reeves (1984, pp. 45-46). Joachim da Fiore, on the other hand, conceived the last great dux rather as a religious leader, prefigured by Salomon, cf. Reeves (1969, p. 304), a detail of further relevance for the Queste, where Galaad inherits the kingship directly from Salomon himself (Queste pp. 201-229). On the possibility of a Joachimist influence in the Queste, see below.
} 
it emphatically the result of a direct divine intervention, ${ }^{46}$ the Queste-author removes the eschatological agency from human hands altogether, returning it to its legitimate divine source and thus discouraging heterodox prophesying and the search for messianic leaders. At the same time, he follows the trend of the contemporary commentators and chroniclers by implicitly exhorting the individual crusaders to engage in an inward regeneration of their spiritual disposition rather than an outward dissipation of their aggressive energy. ${ }^{47}$

\section{III}

The dominant movement of the Queste is therefore that of an inward, contemplative journey. ${ }^{48}$ Yet for all its desire to move away from outward referents into the sphere of the intangible but intelligible secrets of the apocalyptic, divine Liturgy, the Queste, like its heroes almost in spite of itself, keeps falling back into the domain of an inferior, contingent reality. ${ }^{49}$ Unwilling or unable to focus on spiritual realities as such and cultivating a constant alternation between the literal and allegorical, the text explores the endless intersections between the intelligible and the tangible worlds. Yet the mutual pressures and demands of the symbolic and the concrete, of the allegory vs. the romance, remain fundamentally incompatible and account for the persistence of a radical ambiguity that is at once linking and separating these two contiguous yet incompatible degrees of reality in an uneasy convergence. ${ }^{50}$ Ultimately the Queste combines its greatest and most intimate mystical apotheosis-Galaad's spiritual kingship and his contemplation of the divinity "face to face' - with a surprising return to earth. The journey to the city of Sarraz, in fact, etymologically suggests a movement back into the physical space inhabited by the 'Saracens', and thus again suggests the desire for the fixation in space and time of an otherwise invisible spiritual apocalypse. It was already pointed out that, unexpectedly for a romance of the period, neither of the three companions ever confronts the infidel directly, and that the liberation of Sarraz is an entirely peaceful process. While this would seem to suggest a purely allegorical conception of the 'journey' to the Holy City and thus imply an anti-interventionist agenda for the entire work, this

\footnotetext{
${ }^{46}$ Galaad is in fact crowned by the local population obeying a divine injunction, without any further outburst of physical violence, cf. Queste p. 277.

47 See for instance Vallery-Radot (1955, p. 213); Cf. also Siberry (1985, pp. 98-103).

48 This contemplative, even monastic agenda of the Queste has been repeatedly emphasised, e.g., Matarasso (1979, p. 209); Barber (2003); Vallery-Radot (1955, 1956a, 1956b).

49 This has led a number of critics to argue that despite the monastic and contemplative elements, the Queste nevertheless remains primarily a chivalric Romance, e.g., Talarico (1999); Pratt (1995). For an excellent analysis of the problems caused by the reading of the Queste as simple 'romance', and a discussion of the incompatibility of the text's system of values with the ordinary chivalric ones found in the rest of the cycle, see Bogdanow (1986). For a discussion of the lack of narrative and ideological unity within the Vulgate cycle more generally, see Kennedy (2003) and Baumgartner (2003). For an approach that acknowledges the co-existence of multiple perspectives and ideologies while also accepting the Queste's claim to represent the highest and most authoritative point of view, see Kelly (2003).

50 See especially Whitman (1999).
} 
seemingly 'pacifist' passage needs to be read in the light of the narrative episodes that immediately precede it as well as in the context of the contemporary debate about the crusades.

The scenes at Carcelois and the Leprous Castle stand out for their uncompromising brutality and the severity of the ensuing judgement in a text otherwise characterised by its reticence to indulge in physical violence and manslaughter. Also, the stark physicality of the descriptions of the massacre and the divinely ordained destruction plunges the text back into the sphere of the bodily materiality of the romance-genre, ${ }^{51}$ and thus resists the readers' interpretive efforts to allegorise the two massacres as metaphors for an internal, psychomachic struggle of the individual Christian with something like one's 'dark' self. The unexpected and peculiar tone of these passages, combining the apocalyptic with the crudely visual and descriptive, suggests the Queste's desire to present these events as temporal, tangible manifestations of a spiritual, typologically meaningful truth, thus forcing us to accept their twofold, literal and allegorical nature. In doing so the Queste is suspended on a crest that at once separates and attempts to mediate between the need to focus firmly on a spiritual understanding of the apocalypse, and the irresistible hope and desire for a visible, temporal consummation that threatens to relapse into millenarianism. ${ }^{52}$ The literal nature of the destructions of Carcelois and the Leprous Castle, superimposed onto their spiritual, apocalyptic significance, thus reintroduces the issue of a temporal, visible and macrocosmic manifestation of the divine.

As a consequence of this renewed physicality and its literalising implications, the two scenes invite a clearer placement within the historical reality of the crusades and not merely their allegorical, imaginative transpositions. A number of surprising elements in the text now suggest references to specific contemporary events. The text takes care to specify not only that the victims are not pagans, but that they are deviated Christians, specifically described as being 'worse than Saracens' in Carcelois, ${ }^{53}$ and punished for their degenerate, sinful life in the Leprous Castle. ${ }^{54}$ Particularly their description as being 'renegade Christians' (p. 230) and 'worse than Saracens' (p. 231) is rather disturbingly reminiscent of Innocent III's use of this exact phrase to castigate Cathar heretics in his letter of 1208 proclaiming the Albigensian Crusade and exhorting the extermination of all heretics in Languedoc. ${ }^{55}$

\footnotetext{
51 ibid.

52 This split is best summarised by evoking Edwin Honig's differentiation of 'apocalyptic' and 'prophetic', the former defining a transition to an entirely different ontological level, while the latter looks forward to a manifestation of the divine in this world under its present conditions; see Honig (1959, p. 105).

53 "Il estoient poior que Sarrazin, ne faisoient rien qui contre Dieu ne fust et contre Sainte Eglise", (Queste, p. 231). It is clear from the context and the description of the three brothers' abuse of their father and his clergy (p. 232) that they are not simple heathens but degenerate Christians. Cf. also p. 230 where Bors defines them as "gent mescreant et renoiee".

54 Again, the presence of clergy in the Leprous Castle (Queste, p. 240) along with their sinful living (p. 244) confirms their identification as 'bad' Christians. It is equally significant, though, that Perceval's sister, who dies at the castle, receives communion not from the castle's clergy but from a hermit summoned from outside (pp. 241-242).

55 Cf. Innocent III's letter from 10 March 1208, reproduced in Riley-Smith (1981, p. 85).
} 
The extent to which this idea might have entered the common imagination is difficult to assess, but the notion seems to have been shared by the apologists of the Crusade against the Cathars, still in full swing in the late $1220 \mathrm{~s} .{ }^{56}$ In fact, the substitution of Cathar heretics for Saracens as constituting the main threat to the stability of the Christian West in the period seems to have gone as far as allowing their identification with the host of Antichrist itself. ${ }^{57}$ So the massacre of the 20,000 inhabitants of Bézières in 1209 was described by Arnaud Amaury, Cistercian, Bishop of Narbonne and military leader of the Albigensian Crusade in his letter to Innocent III as being "divine vengeance", and a "great miracle", 58 an idea that is again echoed in the Queste's treatment of the two massacres. ${ }^{59}$ Furthermore the identification of the inhabitants of Carcelois with Cathar heretics is not only prompted by their general definition as degenerate and renegade Christians (e.g. p. 230), but may be sustained by specific details of the description. The text insists that they are slaughtered like mute beasts, ${ }^{60}$ which has been read as an allusion to the Cathars' rejection of the doctrine of confession and penance. ${ }^{61}$

If we accept these considerations as confirming the Queste's desire to include an apology of the Albigensian Crusades, this radically alters the text's position in relation to its ideological context as it was sketched above. The mystical, inward drive towards an apprehension of the divine secrets in the intimacy of contemplation is combined, paradoxically, with an outward movement towards the repression of religious diversity. Yet this juxtaposition, for all its seemingly paradoxical nature in our own, modern eyes, rarely seems to have been perceived as such by the age that produced it. For the Queste-author, as for the many Cistercians who were involved in the Albigensian crusade as preachers, papal legates or even military leaders, ${ }^{62}$ there appears to have been no fundamental incompatibility between the monastic focus on a contemplative and mystical spirituality and the endorsement of a militant repression of religious diversity. Both are in fact perceived as complementary forms of a process of inward spiritual regeneration, in one case focused on the isolated individual, in the other on the-forceful-unification of Christianity under the authority of a single Church. A clear distinction between the literal and metaphorical, micro- and macrocosmic dimensions of the struggle against

\footnotetext{
56 This stigmatisation of heretics as being a greater threat than Muslims is shared, for instance, by the troubadour Germonda de Montpelier, cf. Siberry (1985, p. 167), and by the Cistercian Hélinand de Froidmont, repented troubadour, poet, preacher and eventually Bishop of Toulouse, cf. Kienzle (2001, p. 189).

57 Carozzi (1999, p. 111); Emmerson (1981, p. 70).

58 Kienzle (2001, p. 153).

59 So at Carcelois Bors concludes: “Certes, se a Nostre Seignor ne plesoit, ja tant d'omes n' eussons ocis entre nos trois en si pou d'eure'" (Queste, p. 233), and after the storm destroying the Leprous Castle the companions observe that "molt est la venjance Nostre Seignor merveilleuse", (p. 245).

60 "Si les vont ociant et abatant ausi come bestes mues", (Queste, p. 230).

61 Lyons (1952).

62 Kienzle (2001, pp. 1-15 and passim).
} 
erroneous, heretical belief seems to be lacking from the rhetoric that pervades the contemporary exhortations to repress Catharism, ${ }^{63}$ and is reflected in the Queste's attempt at representing a struggle that is both spiritual and military.

This involvement of the text with the literal, physical crusades against the Cathars also radically alters the status of the companions in the narrative as well as the significance of their actions. They are no longer simple miles Christi, as a fullblown allegorical reading would make them, but actual knights whose physicality suddenly re-emerges in these final scenes that precede the consummation in Corbenic and Sarraz. The Queste, thus, while it reiterates the fundamental Christian allegory instructing St. Bernard's De Laude as was already seen, equally perpetuates its fundamentally ambiguous position as negotiating between the literal and allegorical plane of significance. Bernard's miles Christi, after all, is also a Templar knight engaged in an unmistakeably physical, and often tragically literal struggle against the infidel, and not only against moral and theological abstractions. The often invoked, allegedly seamless convergence of the physical role of the Templars with their allegorical significance as miles Christi seems to have failed to persuade Bernard himself, who only reluctantly agreed to address his eulogy to the newly founded military Order. ${ }^{64}$ This irreconcilable ambiguity between the physical and the mystical pervades the entire ideal of the military Orders, originally based on the elaboration of a Pauline biblical allegory that is successively literalised, given a physical, prophetic manifestation in human time and place.

Yet as an attempt to bridge the gap, the historical embodiment itself is perceived as being part of a time-bound but divinely orchestrated, prophetic realisation of an otherwise timeless, apocalyptically meaningful and therefore divine truth. In the light of what was said earlier about the eschatological connotations of the whole crusading impetus, it will in fact hardly come as a surprise to observe that the military Orders themselves were often perceived as playing a major role in the apocalyptic mythology that was constructed around the crusades. ${ }^{65}$ In particular their identification with the heavenly host engaged in the eschatological battle against the army of Antichrist, in turn identified with the Saracen hordes, infidels and heretics, again invited a reading of contemporary events as direct, outward manifestations of apocalyptic prophecies. ${ }^{66}$ In the light of the strong Cistercian element in the Queste, an influence of the Templar ideal has been repeatedly assumed, ${ }^{67}$ and may well extend to include the imaginative assimilation of the Order with the heavenly host. Galaad too, then, striving to become a pure allegory, a

\footnotetext{
63 Kienzle (2001, pp. 9-15 and passim).

64 Cf. Barber (2003, pp. 6-7).

65 Cf. Nicholson (2001, pp. 151-152).

66 The Military Orders are explicitly identified with the heavenly host in Alexander Minorita's Expositio in Apocalypsim (1249), cf. Nicholson (1993, p. 40); the assimilation seems to have been current before that date, as is implicit in several iconographic documents reproduced and discussed by Nicholson (1993, pp. 36, 95) showing the Templars in a fight against the Muslims led by a Lion, traditional figure of the Devil or Antichrist; cf. also Nicholson (2001, p. 40), reproducing a miniature from BL MS Royal 19B XV f. 31, showing an apocalyptic Christ leading the heavenly host in Templar dress.

67 The first to suggest a connection was Pauphilet (1921, pp. 67-68); for latter explorations of the Cistercian-Templar connections, see note 11.
} 
miles Christi with a regenerated inner disposition, nevertheless remains inextricably entangled in the outward business of the crusades. Becoming an elect, pure in body and spirit, he becomes in turn a victim of the identification of the elect with the military orders and thus comes full circle, back into a temporal and bodily existence he appeared to have transcended.

This understanding of the mutual interconnections of the time-bound with the timeless resulting from the intensified apocalyptic climate embraced by the Queste, equally facilitates the identification of pure abstractions with external manifestations. Thus for the Queste the extirpation of heterodox doctrine and the extermination of people following it come to be seen as complementary aspects of a single process of 'inward', mystical and apocalyptic regeneration. The text's didactic insistence on Eucharistic and liturgical symbolism, for instance, can equally be inscribed into its larger, anti-heretical agenda. The Cathars' rejection of the principal Christian sacrament in fact constituted one of the main reasons for their condemnation, in particular after the 4th Lateran Council of 1215 that so emphatically insisted on the sacrament's importance and also resulted in the introduction of the elevation of the host into the liturgy, a detail that is equally echoed in the Queste's emphasis on the desire to 'see' the sacrament. ${ }^{68}$ The insistence on the importance and significance of the Eucharistic ritual thus may be read as constituting yet another element in the text's desire to regenerate Christianity from the inside; it is, as it were, the theological dimension of an overall process of inward purgation that is at once military and ideological, macroand microcosmic. ${ }^{69}$

What is striking about this inward focus of the Queste is its refusal to envisage an active and outward confrontation with the infidel, and the choice, instead, to focus exclusively on the extirpation of an enemy within Christianity itself. This is also a somewhat unusual position when measured against contemporary attitudes that rather tended to criticise the Albigensian Crusade, not so much for its fundamental principle but as constituting a source of distraction from the 'real' crusade to the Holy Land. ${ }^{70}$ The Queste-author, though, adopts the opposite stance, and conceives the Albigensian Crusade not as a distraction from the recovery of the Holy City, but rather as a precondition for its peaceful, divinely ordained restitution to the

\footnotetext{
68 The Henrician heresy in fact seems to have facilitated the advance of Catharism. Henry de Lausanne argued for a purely symbolic function of the Eucharist, where the host simply represented the body of the Lord without actually being transformed into His flesh; this amounted to negating the miracle of the transubstantiation; cf. Vallery-Radot (1956, p. 200).

69 It is intriguing to find in Hélinand of Froidmont a Cistercian, but also poet, chronicler and sermon writer who was not only composing didactic expositions of the doctrine of the Eucharist, writing apocalyptic literature, preaching against the Cathar heresy and participating in the Albigensian Crusade, but who in his chronicle (1211-1223) equally expressed the desire to write a new, more credible and edifying Grail romance in Latin. Cf. Kienzle (2001, pp. 180 ff.). While no such work survives, it is nevertheless striking that the Queste seems to do exactly this: it is edifying, insists on the Eucharist and contains an apology of the Albigensian crusade. While it is tempting to speculate further, stylistic issues and a brief look at his earlier work make Hélinand an unlikely candidate for authorship; the ideological affinity of Hélinand's position with the message of the Queste may nevertheless suggest an indirect involvement in the text's production and deserves further analysis.
}

70 Siberry (1985, pp. 165-167). 
legitimate authority of a purified and unified Christian West. The peaceful transition of kingship from Escorant to Galaad, through the direct agency of divine Grace, is seen as a reward for the companions' previous achievements, at once mystical and military but always directed inwards, towards the heart and unity of Christianity itself. Thus, in answer to the countless appeals for the necessity of a spiritual regeneration of the crusaders' own disposition, the Queste-author conceives the outward victory and recapture of the Holy City as resulting directly and inevitably from this process of spiritual conversion and purgation. This expectation again testifies for the author's belief in an inextricable interconnection between the inward and the outward, the mystical and the historical in the heightened apocalyptic climate of the Grail quest.

Curiously, then, for all its desire to spiritualise the crusading allegory and to discredit literalist messianic prophesying, the Queste cannot avoid taking a brief glance at the hypothetical apocalyptic future brought about by the programme of regeneration it proposes. This amounts to saying that the millenarian apocalypticism that it tries so hard to counteract by an internalisation of the spiritual focus of the quest, again enters the narrative through the back door. While the text resists any explicit, direct and literal identification of outward events with millenarian prophecies, it cannot avoid indulging in its own share of moderate prophetic anticipation and hope for an outward manifestation of the cosmic apocalypse. After all, such is the orthodox and official position of the Christian West, shared and shaped by such crucial figures as St. Bernard and Innocent III, both conjecturing in their own, orthodox terms, the coming eschatology within the framework of the crusades. ${ }^{71}$ More specifically the Queste's relatively careful crusading apocalypticism and its belief in an imminent, peaceful recapture of the Holy City following an internal reunification and regeneration of the Christian West, seems to be indebted, like Innocent III's own reading of the contemporary events, to the writings of Joachim of Fiore. ${ }^{72}$ Far from implying any pacifist message and fundamental criticism of the crusades like the thought of the later Joachites, the writings of the Calabrian Cistercian Abbot in fact postulated an imminent conversion of heretics, Jews and Saracens and the ensuing peaceful recovery of Jerusalem. ${ }^{73}$ While there is little evidence for a wide circulation and influence of Joachim's ideas before the $1240 \mathrm{~s}$, the case for an influence onto the Queste may be strengthened by the important role played in the early circulation of Joachite ideas by both returning crusaders and Cistercians, ${ }^{74}$ both highly relevant for the context and spirit in which the text was produced. An affinity in spirit between the Queste and some Joachite

\footnotetext{
71 For Bernard's apocalyptic expectations see McGinn (1973); Siberry (1985, p. 198). For Innocent III, see Andrea (2004).

72 Andrea (2004, pp. 99 ff.).

73 While Joachim never condemned the crusades or the idea of a Holy War as such, he nevertheless increasingly came to view the crusades as a futile undertaking, attributing the agency for the recovery of Jerusalem to a spiritual, divinely orchestrated process of peaceful conversion heralding the third age of the spirit or status of history. See Daniel (1969); Siberry (1985, pp. 201-206). On Joachim more generally see Reeves (1969).

74 Cf. Reeves (1969, p. 39).
} 
ideas was already pointed out by Pauline Matarasso, ${ }^{75}$ and the argument can be sustained equally by the presence of Joachite elements in the Estoire del Saint Graal, whose author, albeit not identical with the Queste-author, seems to have shared the same Cistercian and general theological background. ${ }^{76}$ The adoption of the Joachite understanding of the eschatology, while it implies the acceptance of an interpretation of the apocalypse as a historical and macrocosmic process, nevertheless postulates an enlarged divine agency in bringing about this consummation, thus avoiding the dualism inherent in many radical, popular millenarian prophecies. Yet in adopting it, the Queste betrays its own, hidden albeit irrepressible thirst for a distant but ultimate and total consummation, micro- and macrocosmic at once, that intervenes in a human timeframe only to annihilate it definitively. And again, being a romance of the body as well as an allegory of the spirit, it confirms its own inability to transcend a latent desire for a terrestrial, visible and macrocosmic revelation of the divine within human history.

\section{References}

Andrea, A. J. (2004). Innocent III, the fourth crusade and the coming apocalypse. In S. J. Ridyard (Ed.), The medieval crusade (pp. 97-106). Woodbridge: Boydell.

Barber, R. (2003). Chivalry, cistercianism and the Grail. In C. Dover (Ed.), A companion to the Lancelot-Grail cycle (pp. 3-12). Woodbridge: D.S. Brewer.

Barber, R. (2004). The holy Grail. London: Penguin

Baumgartner, E. (2003). The Queste del Saint Graal: from semblance to veraie semblance. In C. Dover (Ed.), Companion to the Lancelot-Grail cycle (pp. 107-114). Woodbridge: D.S. Brewer.

St. Bernard of Clairvaux (1977). In Praise of the New Knighthood. Trsl. Conrad Greenia. Kalamazoo: Cistercian Publications

Bogdanow, F. (1986). An interpretation of the meaning and purpose of the vulgate Queste del Saint Graal in the light of the mystical theology of St. Bernard. In A. Adams \& C. E. Pickford (Eds.), The changing face of arthurian romance (pp. 23-46). Cambridge: D.S. Brewer.

Carozzi, C. (1999). Apocalypse et Salut dans le Christianisme Ancien et Médiéval. Paris: Aubier.

Cohn, N. (1957). The pursuit of the millennium. London: Temple Smith (revised 1970).

de Combarieu, M. (1995). Temps Humain, Temps Romanesque, Temps Eschatologique dans la Pentecôte du Graal. In M. Zink \& D. Bohler (Eds.), L’Hostellerie de la Pansée (pp. 119-128). Paris: Presses de L'Université de Paris Sorbonne.

Daniel, E. R. (1969). Apocalyptic conversion: The joachite alternative to the crusade. Traditio, 25, $127-154$.

Emmerson, R. K. (1981). Antichrist in the middle ages. Manchester: Manchester University Press.

Gilson, E. (1932). La Mystique de la Grâce dans La Queste del Saint Graal. In Les Idées et le Lettres (pp. 59-91). Paris: J. Vrin.

Hamilton, W. E. M. C. (1942). L'Interpretation Mystique de la Queste del Saint Graal. Neophilologus, 27, 94-110.

Honig, E. (1959). Dark conceit: The making of allegory. London: Faber and Faber.

Isabel Mary, S. L. G. (1976) The knights of god: Citteaux and the quest of the holy Grail. In Sister Benedicta Ward S. L. G. (Ed.), The influence of St. Bernard (pp. 55-88). Oxford: SLG Press.

Kelly, D. (2003). Interlace and the cyclic imagination. In C. Dover (Ed.), A companion to the LancelotGrail cycle (pp. 55-64). Woodbridge: D.S. Brewer.

\footnotetext{
75 Matarasso (1979, p. 94).

76 Barber (2003, p. 11). Baumgartner (2003, p. 113) interprets the three branches of the Tree of life, found on the ship of Salomon as representing three distinct ages of human history, associated with the Father, the Son and the Holy Spirit, respectively. Such a Trinitarian conception of history reflects one of Joachim's core-doctrines and further sustains the case for an influence of his ideas on the Queste.
} 
Kennedy, E. (2003). The making of the Lancelot-Grail cycle. In C. Dover (Ed.), A companion to the Lancelot-Grail cycle (pp. 13-22). Woodbridge: D.S. Brewer.

Kienzle, B. M. (2001). Cistercians, heresy and crusade in occitania 1145-1229. Woodbridge: York Medieval Press.

Knight, S. (1994). From Jerusalem to Camelot: King Arthur and the Crusades. In: P. R. Monks \& P. D. R. Owens (Eds.), Medieval codicology, iconography, literature and translation (pp. 223-232). Brill: Leiden.

Lot-Borrodine, M. (1951). Les Grands Secrets du Saint Graal dans la Queste du pseudo-Map. In R. Nelli (Ed.), Lumière du Graal (pp. 151-174). Paris: Les Cahiers du Sud.

Lyons, F. (1952). Huon de Méry's Tornoiement d'Antéchrist and the Queste del Saint Graal. French Studies, 6, 213-218.

Matarasso, P. (1979). The redemption of chivalry. Genève: Librairie Droz.

Mayer, H. E. (1972). The crusades. Oxford: Oxford University Press.

McGinn, B. (1973). St Bernard and eschatology. In Bernard of clairvaux: Studies presented to Dom Jean Leclercq (pp. 161-86). (v.a.) Cistercian Studies Series XXIII. Washington, D.C.: Cistercian Publications.

Nicholson, H. (1993). Templars, hospitallers and teutonic knights: Images of the military orders. Leicester: Leicester University Press.

Nicholson, H. (2001). The knights templar. Stroud: Sutton Publishing.

Pauphilet, A. (1921). Etudes sur la Queste del Saint Graal. Paris: Honoré Champion.

Pauphilet, A. (Ed.) (1923). La Queste del Saint Graal. Paris: Champion.

Piper, O. A. (1951). The apocalypse of John and the liturgy of the ancient church. Church History, 20(1), $10-22$.

Pratt, K. (1995). The cistercians and the Queste del Saint Graal. Reading Medieval Studies, 21, 69-96.

Reeves, M. (1969). The influence of prophecy in the later middle ages. Oxford: Oxford University Press.

Reeves, M. (1984). The development of apocalyptic thought: medieval attitudes. In: C. A. Patrides \& J. Wittreich (Eds.), The apocalypse in english renaissance thought and literature (pp. 40-73). Manchester: Manchester University Press.

Ridyard, S. J. (Ed.) (2004). The medieval crusade. Woodbridge: Boydell.

Riley-Smith, J. (1987). The crusades: A short history. London: The Athlone Press.

Riley-Smith, L., \& Riley-Smith, J. (1981). The crusades: Idea and reality 1095-1274. London: Edward Arnold.

Runciman, S. (1955). A History of the Crusades, Vol III. Cambridge: Cambridge University Press.

Saycell, K. J. (1991). Romance and mysticism: St. Bernard and the XIIIth century arthurian vulgate cycle. Unisa English studies, 29(1), 1-7.

Siberry, E. (1985). Criticism of crusading 1095-1274. Oxford: Oxford University Press.

Spiewok, W. (1989). La Signification de la Croisade dans la Littérature Allemande du Moyen Âge Classique. In: D. Buschinger (Ed.), Croisade: Réalité et Fictions: Actes du Colloque d'Amiens, 1987 (pp. 11-22). Göppingen: Kümmerle Verlag.

Talarico, K. M. (1999). Romancing the Grail: Fiction and theology in the Queste del Saint Graal. In: P. Meister (Ed.), Arthurian literature and christianity (pp. 29-59). New York: Garland Publishing.

Trotter, D. (1988). Medieval french literature and the crusades 1100-1300. Genève: Droz.

Tyerman, C. (1998). The invention of the crusades. Basingstoke and London: Macmillan.

Vallery-Radot, I. (1955). Les Sources d'un Roman Cistercien: La Queste del Saint Graal. Collectanea Ordinis Cisterciensium Reformatum, 17(3), 201-213.

Vallery-Radot, I. (1956). La Queste del Saint Graal: Roman Cistercien. Collectanea Ordinis Cisterciensium Reformatum, 18(1), 3-20(a); 18(3), 199-213(b)

Whitman, J. (1999). The body and the struggle for the soul of romance: La Queste del Saint Graal. In: P. Boitani \& A. Torti (Eds.), Body and soul in medieval literature (pp. 31-62). Cambridge: D.S. Brewer.

Williams, A. M. L. (2001). The adventures of the holy Grail. Oxford: Peter Lang. 